\title{
METACOGNITION AS A TOOL TO IMPROVE WRITING IN A SECOND LANGUAGE'
}

\section{LA METACOGNICIÓN COMO HERRAMIENTA PARA MEJORAR LA ESCRITURA EN UN SEGUNDO IDIOMA}

Jacqueline García-Botero ${ }^{1 *}$ (D); Larissa Tatiana Rico-Buitrago ${ }^{2}$; Margarita Alexandra Botero-Restrepo ${ }^{3}$ (D.

1. Master in Education in University of Quindío, Colombia. jgarciab@uniquindio.edu.co

2. Professor at the University of Quindío, Colombia. rblarissa@uniquindio.edu.co

3. Master in Foreing language teaching and discurse analysis (Universidad Pedagógica-Universidad Nantes), Colombia. mabotero@uniquindio.edu.co

*Corresponding author: Jacqueline García-Botero, email: jgarciab@uniquindio.edu.co

\begin{abstract}
This action research was developed with professors and students from the Modern Languages program at the University of Quindio. An intervention strategy was designed to improve the performance of individual participants in regards to their written skills. The strategy aimed at providing a clear explanation of the mistakes found, placing the student into a position to consciously avoid them in future writings. The categories that emerged from the instruments and procedures performed were: utility, content and evaluation, showing that this proposal is an efficient alternative to improve English writing.
\end{abstract}

Keywords: metacognitive tool; metacognition; strategy; writing.

$1 \quad$ This article is part of the investigation 716 "la metacognición como herramienta para mejorar la escritura academica" financed by the University of Quindío, Colombia.

Cómo citar:

García-Botero, Jacqueline; Rico-Buitrago, Larissa Tatiana; Botero-Restrepo, Margarita Alexandra. (2021). Metacognition as a tool to improve writing in a second language. Revista de Investigaciones Universidad del Quindio, 33(2), 236-247. https://doi.org/10.33975/riuq.vol33n2.468

Información del artículo: Recibido: 30 abril 2021; Aceptado: 5 noviembre 2021 


\section{RESUMEN}

La presente investigación acción fue dirigida a docentes y estudiantes del programa de Licenciatura en Lenguas Modernas de la Universidad del Quindío. Se diseñó una estrategia de intervención la cual buscó mejorar el rendimiento individual de los participantes. La estrategia pretende dar una explicación clara del porqué del error cometido, situando al estudiante en una posición más consciente que le permite evadir el error en próximas redacciones. Las categorías que emergieron desde los instrumentos y procedimientos efectuados fueron las siguientes: la utilidad, el contenido y la evaluación, evidenciando que la herramienta propuesta es una alternativa eficiente para el mejoramiento de la escritura en inglés.

Palabras claves: estrategia; escritura; herramienta metacognitiva; metacognición.

\section{INTRODUCTION}

It cannot be ignored that being writing a complex ability that requires an intentional instruction, it follows a conscious process where different skills are developed. In the teaching / learning of a second language, writing is part of one of the most complex processes because learners have to deal with all the cultural background that their mother tongue embodies, to face a new language experience. In the Modern Languages program, at the University of Quindio, it is intended that the trainee be able to express his/her ideas not only from an oral, but from a written way in order to "build" a competent professional in all skills. In addition, it is expected that by the end of the fourth semester, students can express themselves properly in a L2 following the syntactic, pragmatic and semantic rules of English. However it has been shown that students have difficulties with the English language; This is mainly evidenced by the results of the MICHIGAN test where many shortcomings can be found, especially in writing. From there, then, the search for strategies that help to improve this skill has become a very important task for both professors and students. Is then where this research arises, persuing several objectives.

\section{General Objective}

To qualify expository writing in L2 through metacognitive strategies.

\section{Specific Objectives}

- To diagnose students' writing level in terms of the dimensions and levels of the text proposed by Morris (syntactic, semantic and pragmatic).

- To design an intervention plan (also called metacognitive strategies) in order to face the problems encountered.

- To assess the scope reached by the intervention plan.

\section{LITERATURE REVIEW}

Metacognition is the ability one has to know one's knowledge (Barranco, 2007). When an apprentice is able to recognize the difficulties to do something, this person is using his/her metacognitive awareness. But metacognition goes beyond the acceptance of what we can not do; that is, when an apprentice has difficulty identifying something, the next step should be seeking possible solutions to those weaknesses; in Barranco's words (2007: 194) “Metacognition means knowing what you do not know, being aware about what you do not know and looking for ways and means to solve that problem of lack of knowledge."

For language learning, this concept becomes very important because, as the student is aware of the problems that can occur in the acquisition of a language, he/she can find ways to solve them. 
Also, when the learner is aware of the linguistic functioning of their language, he/she can do positive relations when learning an additional language.

\section{The role of Errors in Language Learning}

Every learning process involves making mistakes. In fact, mistakes have been considered as an essential part of learning since based on them we can build knowledge. In the case of language learning, learners inevitably make mistakes because they are in the process of building a new language system which they had not been exposed to. On the other hand, as indicated by Corder (1973) errors are important because they provide evidence for researchers to analyze how languages are acquired or learned through the analysis of all the strategies and procedures that learners performed to discover the new language. However, it is not enough to recognize that mistakes are part of learning and are an essential source for understanding thereof; it is also necessary to realize that failure to deal with the mistakes of language learning can generate a series of obstacles to proper language development. Lies here, then, the importance of studying the mistakes, because from them, you can find strategies that help the learner to improve their performance in an additional language.

\section{Bilingualism}

Taking a unique approach to bilingualism can be inconvenient since this term is such a wide and interdisciplinary concept; among the most appropriate definitions that does not fall into maximalisms or minimalism, we find Galindo's approach to this concept defining it as : "the ability possessed by a person (individual bilingualism) or community (social bilingualism) to use two or more languages-cultures with varying degrees of control in relation to the external environment involved in such use." (Galindo, 2009). It is interesting to recognize that learning a language is not only knowing the linguistic rules about it, but also the socio-cultural knowledge that each language carries. Hence, metacognition as a cognitive process that seeks self-assessment of knowledge, must transcend the linguistic rules themselves; It is why the written productions of bilingual students were evaluated not only from the syntactic but also from the semantic and pragmatic dimension because a bilingual is not only who knows the syntax rules of the language but also the one who knows how to use communication with a clear intension, depending on a given context.

\section{Text Dimensions and Levels}

Semiosis, defined as "the process in which something functions as a sign" (Morris, 1985: 27) comprises the relations of signs to objects (semantics), interpreters (pragmatic) and the formal relationship between the signs (syntax).

The syntactic dimension, refers to the formal use of language; that is, the language becomes a set of syntactic rules that follow a grammatical logic. In this sense, from this dimension, all the factors that give the appropriate / inappropriate use of grammatical structures corresponding to the English language were considered.

In the semantic dimension, language is analyzed from the "signifying vehicles"; that is, part of the logical relationship between the sign and the situation in which it is determined. Morris maintains that as a sign can have a usage rule to determine what it may mean (...)

There are signs that, in fact, do not denote anything or have a nule denotation (Morris, 1985: 61). Given this dimension, the analysis of students' written productions considered if the words used give a coherent meaning to the sentences used or not.

Finally, the pragmatic dimension refers to the relationship between the signs and the performers; that is, "the habit of the interpreter of using the signifying vehicle in given circumstances". From this dimension, we must 
recognize that a language is inextricably linked to the culture to which it belongs; hence, to handle two or more languages, the individual also faces a wealth of cultural differences; he/she has to recognize all those social practices that each of the languages involved so as to prompt effective communication. From there, then, analyzing students' written productions was made from the usage of the word in a given context; in this case, from the different contexts that the two languages provide.

\section{Written Production}

Writing as social, intentional and reflective process that allows the production of a series of linguistic codes that create a message and make a text (understood as a communicative and structured object (Camargo et al, 2008), is a permanent construction and a complex process that, seen from the cognitive and linguistic point, requires certain skills to perform it efficiently. It is also an independent and complete language that transcends the simple act of transcribing the oral language (Cassany, 1994) and a "linguistic activity (...) focused on the use of language to written expression of meaning" (Galindo, 2008). In the case of writing in a foreign language, the process also involves, as explained Cassany (2001), learning to use one's own cultural artifacts of the community to which it belongs to, and thus achieving optimal results in reading and writing.

\section{Expository Texts}

Regarding the reading process, various text types frame a path to follow depending on the communicative intention of the writer; in this case, the narrative text as a research unit of the present proposal is presented below.

JM Adam (1992) describes the narrative text as a text type whose communicative purpose is to provide an understanding of a subject from various linguistic elements such as quotes, definitions, descriptions, references, logical connectors, etc; also, it can be used in various speech genres such as textbooks, manuals, conference papers, etc.

The choice of this type of text in particular was due to the fact that even being expository texts the most common type of text in the academic context, students are not able to cope with it in an appropriate level and domain since, as expressed by T. Alvarez (2000: 106): the paradox that being this type of text the most used in the academic sphere, and however there is not systematic training in the linguistic area, traditionally centered on the writting of descriptive and narrative texts (...).

\section{Literature review}

Some researches done at local, national and international level studying metacognition as a significant process in reading and writing in LM and L2 are very important to understand the basis of this project.

In the national context, the exploratory research conducted by the research group cognition and language in Childhood at the Universidad Nacional de Colombia called "metalinguistic skills and metacognitive operations and its relationship with is the proficiency levels in reading and writing. An exploratory study "explains how one hundred eighty (180) children between five and ten years from different social strata, make relationships with metalinguistic skills levels in reading and writing in Spanish. Among the most important findings of this study the group found that while students are progressing in their education level, the performance in terms of metacognition operations improves both in reading and writing. In addition, it was determined that the students who belong to a higher social strata, developed more their metacognitive capacity than students from lower social strata. Importantly, this study demonstrates how, from very early ages, you can make use of metacognition to reflect on the language itself and make judgments, not 
only from form, but from the content of speech. The authors concluded that the practices of teaching / learning are, at the end, a stimulant for the development of metalinguistic abilities since it is there where they can offer meaningful experiences that help such development.

In the international context, Reyes and Susana (2006), University of Tachira, Venezuela, conducted a study called "lexical and syntactic interference of the second language in the mother tongue at a seminar of Introduction to Translation." The main objective of this study was to identify various categories of linguistic interference (English-Spanish) from the use of the portfolio to propose pedagogical interventions that help the resolution of errors made. This time, the studied population consisted of 34 students from the University of Táchira Venezuela who were part of a translation course where their written productions were analyzed. They kept a portfolio, where the difficulties were identified when translating English and Spanish texts; the use of a portfolio served as a metacognitive strategy for students to assess their own process and progress as translators.

\section{MATERIALS AND METHODS}

The result of this action research is a metacognitive tool to correct paragraphs and essays. The project carried out several stages:

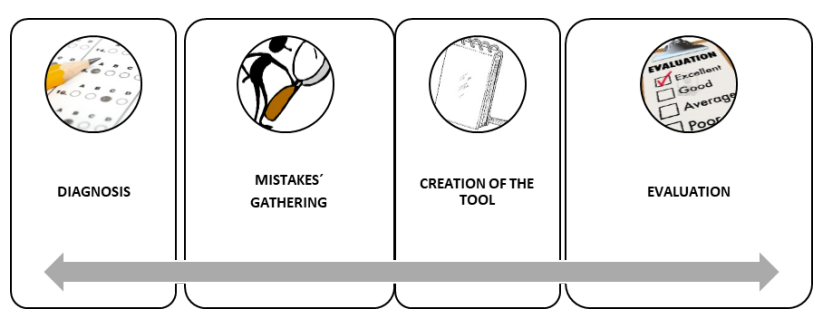

The diagnosis field consisted on measuring students' level in regards to writing. They were provided an image and they had to write a narrative text with it. The mistakes' gathering phase consisted on a thorough observation of students' common mistakes (using the field notes instrument); this phase also included professors' feedback (professionals including their contributions to the tool).

The creation of the tool was done next. It consisted in a printed guide with forty nine syntactic, ten semantic and five pragmatic challenges. Currently, the tool is shown as an application for tablets, cellphones and computers so it becomes more accessible and enjoyable for both students and professors. Finally, the evaluation phase was developed so as to verify advantages and disadvantages of the tool. You can download the application in Playstore as "metacognitive challenges"

\section{RESULTS AND DISCUSION}

Before carrying out any action on the context, it was necessary to do a diagnostic test to be aware of students' written level of expository texts in English. To do so, students were asked to make a story from an image (see Appendix A ). The texts collected were assessed from an evaluation rubric divided into three areas (semantic, syntactic, pragmatic) (see Appendix B). The results obtained show that both groups have an adequate written level with an average of 80 and $81 \%$ respectively as measured with the rubric. However, higlighting the individual performance of each participant, they showed great difficulties mainly in the syntactic field, and more specifically, in the use of punctuation, verbs conjugation and connectors in the text, causing, at the same time, difficulties in the semantic field. It is important to recognize that punctuation is important since it provides a better understanding of the text and avoids ambiguities (Rosello-verdeguer \& Roselló-verdeguer, 2013); Similarly, the correct use of connectors provides coherence and cohesion to the text expressing different relationships: causal, contrast, addition, comparison, among others to give a global meaning to it (Diaz Rodriguez, nd). Finally, the conjugation of verbs allows a logical sequence that puts the reader in a certain time and offers, likewise, coherence to the text; There is when the importance of these aspects in expository writing 
and the need to search for strategies to improve individual levels of writing arises.

\section{Categories and Subcategories}

The categories and subcategories that emerged from the instruments and procedures performed are:

\section{Category 1: Usefulness}

- Usefulness in Learning: as shown in the results obtained from the workshop with students, using the tool helped in several ways: to improve writing skill, to become more aware of their own learning, to recognize the source of the mistakes in their compositions, and to have a better preparation for the MICHIGAN exam. Here some comments made by students:

Student 1: It helps to improve our writing Student 18: We can see lots of common mistakes and the way in which we can correct them

Student 8: This tool leads us to be more careful when writing

Student 16: (...) when we'll take the MET we will have an excellent grade in the writing part

Students'comments regarding the improvement in their compositions can also be evidenced in the results obtained from the application of a final test which followed the same characteristics of the diagnostic test; in there, a great improvement was shown (group 1: 88\% Group 2: 95\%) and, mainly, individual improvement was identified. Certainly, using metacognitive challenges allows students to be more aware of their own learning, correcting those aspects that cause difficulty being the end of metacognition, as expressed by Barranco (2007) "Metacognition means realizing that you do not know to do something. The next step is to ask why we have a particular difficulty, and then consider how to resolve it".

- Usefulness in Teaching: In the case of the two teachers who explored the tool, they said it was useful in different aspects: it served as a strategy to provide feedback to students, to learn some rules of which they themselves were unaware, to qualify their assessment strategies, and to challenge students to learn more about their knowledge. Some of the teachers' comments were:

\section{Teacher 1}

- I consider it as a very useful teaching tool. It helps students to be aware of their own mistakes and to find solutions, because it is not the teacher who must respond to the difficulties, but students themselves.

- This teaching guide helped me to clarify some doubts

- (...) they became aware of the mistakes they made

\section{Teacher 2}

- After using it several times, it become easier to be used.

- From this tool, I decided to ask students to create a folder in which students reported their mistakes (...)

- It is helpful for students so that they can correct themselves, so they can identify the mistakes they have and what their most common faults are.

Certainly, the use of the tool sought to enrich the way in which teachers corrected their students; generally, the way in which teachers check students' compositions is higlighting the mistake in red which sometimes can be confusing for them or simply, professors make use of holistic rubrics to give a general approach to students' writings; but very few strategies actually emphasize the need to know the source of the mistakes, for students to avoid it in the future which is, indeed, the goal of this metacognitive strategy. Actually, there are times when professors can not justify the source of the mistake committed by students since their use of grammatical, pragmatic and semantic rules are used naturally, almost 
mechanically; This is why this metacognitive tool becomes a useful tool for them, who can find and adequate response to questions raised by students.

What was manifested by the participants in that the tool becomes more agile to make corrections is an advantage when one considers that whenever the strategy is used more frequently, metacognitive challenges will be learned in some "mechanized" manner, contributing greatly to the work of teachers. The fact that metacognitive tool also motivates them to make further changes in their way of evaluating is a way of contributing to "updating" the teaching practice; It is important to remember that teachers' professional development should be in constant dynamism; a teacher who evaluates his/her own practices tends to improve and be at the forefront of the new changes that society demands. Finally, the fact of challenging students to go beyond what they write, to find their own mistakes and their solutions, the teacher becomes more of a guide to learning, leaving aside the authoritarian role that is still evidenced in some institutions.

\section{- Usefulness in The Modern Languages Program}

After socializing the project with the teaching staff, especially professors in basic courses of the Modern Languages program, they chose to use the tool in their courses for the period 2015-2 to assess the usefulness of the tool not only in the third semester, but from the second to the fifth semester as it was considered something new, complete and useful becoming in a good way to give feedback to students. Likewise, professors expressed the need to unify criteria in regards to the way in which students' are graded, not only from a quantitative but from a qualitative tool (such as this strategy). Nowadays, the tool is still being used by professors; this time they use the application "metacognitive challenges".

The teachers also arrived to the conclusion that being this tool a qualitative strategy, it could be expanded with recommendations for all academic community who would use it during the current period so that no metacognitive challenge could "escape" when checking. This interest of teachers to apply new evaluation techniques, and somehow change their beliefs about the proper way to provide feedback to students, responds to what is expected of teacher development.

\section{Category 2: Content}

- The Form of Document: regarding this subcategory, both professors and students reported finding a very long document, which does not allow them to make corrections of the texts in an agile way; they expressed the following comments:

Student 1: The document is very EXTENSIVE; It becomes tedious in the moment of correction. Student 3: It is a little complicated to understand, since it has many things to read and take into account.

Student 4: (...) Maybe it is very EXTENSIVE Makes the correction longer.

Student 7: The difficult aspect about this is the amount of rules that the metacognitive strategies have, because it is really difficult to memorize them.

Student 9: We can't understand the correction at the time that the teacher gives us our exams.

For teachers, they retain the same concern, but show a more positive attitude to this feature, they determine this factor as a difficulty for students, not for them directly.

\section{Teacher 1:}

Some students do not have enough money to print, it was important to give everyone a copy.

\section{Teacher 2:}

(...) Suddenly students think it was very long for them.

Well, when you see it for the first time you say, oh! That tool is so long because I usually 
use fewer symbols (...) I think it becomes very interesting to use it and it becomes mechanical for one.

To adress these difficulties, the application "metacognitive challenges" was created. It has been currently used by professors and students of the program and it has shown positive reactions in the academic community.

- Profoundness of the Document: Regarding the content of the strategy, both students and teachers manifested they found a very useful and complete tool that identifies many of the mistakes committed in their writings; also, teachers expressed that some metacognitive challenges were not outlined in the document. On this subject they expressed as follows:

Student 1: the document has very clear information which makes understanding easier. Student 5: It is a little very complete dictionary. Student 19: giving the opportunity to the student to know what is wrong is good to improve in those aspects and make him/her to avoid the mistake in the future.

Student 20: This is clear at the time of correcting our paragraphs.

Student 22: There are lots of examples to learn how to correct our paragraphs.

Teacher 1: The explanations of the mistakes are very clear

Everything is very clear

I believe that (...) we should add some missing information, some mistakes that students made were not included within the points of the tool, for example the conjugating of the present simple (she do), etc

Teacher 2: (...) a disadvantage could be that I noticed or found missing some (...) metacognitive challenges, sometimes I did not find the mistake, then I had to use the symbols that I usually used.
I think the tool is very well designed, I think that's fine, the only thing would be to include some missing elements but I think it is a great tool that is very useful.

All these concerns about the form and content of the document, were also treated in the focus group of reading and writing teachers who contributed to its improvement; from 43 metacognitive challenges in the syntactic field proposed at the beginning, a total of 51 was obtained; from 2 in the pragmatic level, there were two more; the semantic field remained in the same way. There is no doubt that this collective construction of the document further contributes to its validity and usefulness.

\section{Category 3: Evaluation}

- Evaluation of Learning: This subcategory has only positive comments since it gives students the opportunity not only to identify their mistakes, but also to know their source, fix them and avoid them in future compositions; some examples of this statement were:

Student 2: students can learn from mistakes and review what they have already learnt, but they have forgotten.

Student 5: you can easily recognize which kind of mistakes you did, and the correct way of repairing it.

Student 7: The metacognitive strategies teach you how to correct in a good way your mistakes, and in the same way, to prevent you of making them again, That is, you get too much knowledge which helps you to improve every time.

Student 9: It Makes the correction process more complete and productive.

The use of metacognitive tool achieved in the student an active autonomous learning, making them conscious of their own knowledge. 
- Evaluation of Teaching: In the case of teachers in this subcategory it was analyzed whether the strategy contributed to a renewal in the way they evaluate. Both, research participants and basic courses teaching staff, agreed with the tool as a complete new and useful way to evaluate.

In the case of participant professors, one of the questions in the semi-structured interview was directed toward this end: would you use this tool to check students' compositions again? Why?

Teacher 1: Yes, because most of them understand why their difficulties were, and they improved significantly in the written part.

Teacher 2: I think it would be possible because it is very detailed, as I said, it is a tool that can be of great help to students so that they can be corrected giving them useful feedback.

In the case of professors in basic courses, as already mentioned, they have adopted the tool to be used from second to fifth semester courses in literacy during the period 2015-2. Nowadays is still being used with the help of technology.

\section{CONCLUSIONS}

- Metacognition as a tool for teachers and students is an alternative to correct academic texts that provides teachers with an innovative strategy; and allow students to receive an accurate feedback.

- Students, being aware of their own learning, avoid the mistakes that they have always made in future assignements, thereby improving their writing skills.

- There is a positive attitude towards the use of the tool; Thus it became a base strategy for correction of academic texts.

- The metacognitive tool is now available in google play. You just need to type "Metacognitive challenges" and you can use the application for free.

- How to Use the Metacognitive Challenges: The idea is to download the application. Then, when you receive the paragraph or essay, you start identifyng the mistakes and writing the symbol they should look for in the document.

Example 1: I am not agree with you (you as professor, write: Sc23 which means: sintactic challenge number 23).

Then, students will revise the document and will find the correct way of writing that sentence:

Use the verb agree and the noun agreement differently.

Example 1: Iam agree with you

Correction: I am in agreement with you OR I agree with you.

Example 2: students write:

"IT DOESN'T MATTER" (you as a teacher, write: PC 1 which means: go to pragmatic challenge number 1)

Then, the student looks for it and finds:

- Avoid contractions; they are informal in academic writing.

Example: It doesn't matter

Correction: It does not matter 


\section{REFERENCES}

1. Adam, J.M. (1992). Les textes: types et protoypes. Récit, description, argumentation, explication, dialogue.[The texts: types and prototypes. Recite, description, argumentation, explanation, dialogue] Paris: Nathan.

2. Álvarez, T. (2000). Tipología de textos y enseñanza de la lengua. [Texts typology and language teaching]. Madrid: U.C.M

3. Barranco, J. (2007). Metacognición, Motivación y Autoevaluación en el Proceso Lector. [Metacognition, motivation and self-evaluation in the Reading process]. XVIII Congreso internacional de la asociación para la enseñanza del español como lengua extranjera (ASELE).

4. Camargo, Z. Uribe, G. Caro, M. Castrillón, C. (2008). Análisis de una muestra representativa de los relatos presentados al Concurso Nacional de Cuento Gabriel García Márquez (2007). [Analysis of a representative simple of stories presented to the National Stories Contest Gabriel García Márquez (2007)]. Grupo de investigación en Didáctica de la Lengua Materna y la Literatura (DiLeMa). Armenia, Colombia.

5. Cassany, D, (2001). Huellas de la escritura maternal en el español escrito como L2. [Maternal writing footprints in written spanish as a L2]. Zona Próxima: (15) 122-133. Fundacion Universidad del Norte.

6. Cassany. D. (1994). Describir el escribir.[Describing writing]. Barcelona: ediciones Paidós.

7. Corder, S. Pit (1973). Introducing Applied Linguistics. Harmondsworth, UK: Penguin Books.

8. Diaz Rodriguez, A. (n.d.). Coherencia Interna. [Inner coherence]. Universidad ICESI.

9. Galindo, A y Moreno, L (2008). Produccion argumentativa escrita-lengua materna- en contextos educativos bilingües y monolingües: grados 67 y 8. [ argumentative written production- mother tongue- in bilingual and monolingual contexts: 6, 7 and 8 graders]. Íkala, 13 (19). Universidad de Antioquia.

10. Galindo, A. (2009). Bilinguismo, habilidades metalinguisticas y lenguaje escrito. Acercamiento teorico-experimental. [Bilingualism, metacognitive skills and written language. Theoreticalexperimental approach]. Armenia: Editorial Kinesis.

11. Morris, C. (1985). Fundamentos de la Teoria de los signos. [Theory of signs fundamentals]. Ediciones Paidós: Barcelona.

12. Reyes Yañez, Fabiola Susana. (2006). Interferencia léxica y sintáctica de la segunda lengua en la lengua materna en un seminario de iniciación a la traducción. [lexical and sintaxis interference of a second language in the mother tongue in an iniciation seminar of translation]. Acción Pedagógica, no 15 / Enero - Dicembre, 2006 - pp. 34-43. ULA Táchira. Venezuela.

13. Roselló-verdeguer, J., \& Roselló-verdeguer, J. (2013). La responsabilidad del profesorado en la enseñanza de la puntuación. [Professors'responsibility in the teaching of punctuation]. Revista de Linguistica Y Lenguas Aplicadas, 8, 33-37. 


\section{APPENDIX A}

1. Now, look at the image, and write a story (write in English).

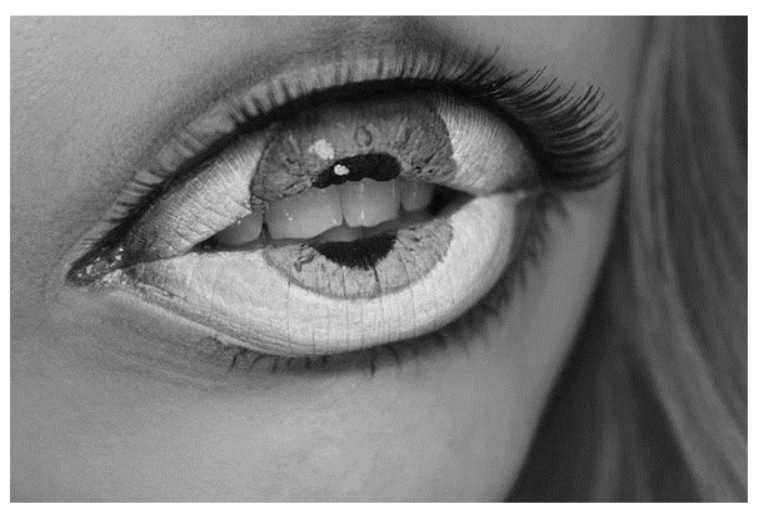


APPENDIX B

\begin{tabular}{|c|c|c|c|c|}
\hline DIMENSION & CRITERIA & & & EXAMPLES \\
\hline & & \begin{tabular}{l|l|l|l|} 
& 2 & 3 \\
\end{tabular} & \begin{tabular}{|l|l|l|}
4 & 5 \\
\end{tabular} & \\
\hline \multirow{16}{*}{ Sintax } & $\begin{array}{l}\text { 1-Knows the orthography of the words } \\
\text { used. }\end{array}$ & & & \\
\hline & 2-. Conjugates the verbs correctly. & & & \\
\hline & 3- Follows agreement subject-verb. & & & \\
\hline & $\begin{array}{l}\text { 4- Registers correctly the use of } \\
\text { punctuation marks. }\end{array}$ & & & \\
\hline & 5- Builds simple sentences correctly.. & & & \\
\hline & $\begin{array}{l}\text { 6- Builds compound sentences } \\
\text { correctly. }\end{array}$ & & & \\
\hline & $\begin{array}{l}\text { 7- Uses logically verbal tenses in his/ } \\
\text { her text. }\end{array}$ & & & \\
\hline & 8- Identifies the use of capitalization. & & & \\
\hline & 9-. Uses prepositions correctly. & & & \\
\hline & 10- Follows agreement article-noun. & & & \\
\hline & $\begin{array}{l}\text { 11. Follows agreement adjective- } \\
\text { noun. }\end{array}$ & & & \\
\hline & 12. Uses adverbs correctly. & & & \\
\hline & 13. Uses connectors appropriately. & & & \\
\hline & 14 Uses deictics appropriately. & & & \\
\hline & 15. Uses parallelism correctly. & & & \\
\hline & 16. Uses possesive forms correctly. & & & \\
\hline \multirow{4}{*}{ Semantic } & 17. Uses synonyms appropriately. & & & \\
\hline & $\begin{array}{l}\text { 18. Gives to the reader a wide context } \\
\text { to understand the meaning of his/her } \\
\text { words. }\end{array}$ & & & \\
\hline & $\begin{array}{l}\text { 19. Chooses the right words to what } \\
\text { he/she wants to express. }\end{array}$ & & & \\
\hline & $\begin{array}{l}\text { 20. Demonstrates knowledge of the } \\
\text { several meanings of words. }\end{array}$ & & & \\
\hline \multirow{3}{*}{ Pragmatic } & $\begin{array}{l}\text { 21. Answers to the types of texts } \\
\text { requested. }\end{array}$ & & & \\
\hline & $\begin{array}{l}\text { 22. Shows the process of revision, } \\
\text { correction and re-writing. }\end{array}$ & & & \\
\hline & $\begin{array}{l}\text { 23. Uses different levels of formality } \\
\text { according to the audience. }\end{array}$ & & & \\
\hline
\end{tabular}

